\title{
Article \\ Student Speech and Social Media: The Supreme Court Finally Enters the Fray
}

\author{
Charles J. Russo 1,2 \\ School of Law, University of Dayton, Dayton, OH 45469, USA; crusso1@udayton.edu \\ 2 School of Education and Health Sciences, University of Dayton, Dayton, OH 45469, USA
}

\begin{abstract}
Tinker v. Des Moines Independent Community School District was a watershed moment involving the First Amendment free speech rights of students in American public schools. In Tinker, the Supreme Court affirmed that absent a reasonable forecast of material and substantial disruption, educators could not discipline students who wore black arm bands to school protesting American military action in Viet Nam. Not surprisingly, litigation continues on the boundaries of student speech, coupled with the extent to which educators can limit expression on the internet, especially social media. As the Justices finally entered the fray over cyber speech, this three-part article begins by reviewing Tinker and other Supreme Court precedent on student expressive activity plus illustrative lower court cases before examining Levy v. Mahanoy Area School District. In Levy, the Court will consider whether educators could discipline a cheerleader, a student engaged in an extracurricular activity, who violated team rules by posting inappropriate off-campus messages on Snapchat. The article then offers policy suggestions for lawyers and educators when working with speech codes applicable to student use of the internet and social media by pupils involved in extracurricular activities.
\end{abstract}

Keywords: student speech; First Amendment; social media

\section{Introduction}

More than fifty years ago, the United States Supreme Court's ruling in Tinker v. Des Moines Independent Community School District (Tinker) ${ }^{1}$ represented a watershed moment involving the First Amendment free speech and expression rights of students in American public schools.

In Tinker, the Justices affirmed an order of the federal trial court in Iowa that absent a reasonable forecast of material and substantial disruption, educational officials could not discipline students who expressed their views in protest against American military action in Viet Nam by wearing black arm bands to school. At the same time, while Tinker was the initial case recognizing the First Amendment free speech rights of students in public schools, as discussed below, ${ }^{2}$ it turned out to be the high watermark for the protections the judiciary would afford expression in its three later judgments on this important topic.

Not surprisingly, litigation continues on the boundaries of student free speech and the extent to which educational officials can limit the expression of pupils in the newest, continually expanding, ${ }^{3}$ forum for student expression, the internet, especially in the form of social media. To date, perhaps because of the speed at which the use, and misuse, of technology in schools advances, the Supreme Court has been reticent to accept a case involving student speech involving the use of technology.

Aware of ongoing conflicts over student use, and misuse, of technology in and around schools, the Supreme Court has finally entered the fray in this latest battle ground in the

\footnotetext{
393 U.S. 503 (1969). For a fairly recent, representative commentary on Tinker, see (Papandrea 2019).

See infra notes 10-16 and accompanying text.

For representative commentaries on point, see (Sweeney 2018; Russo 2018, pp. 35-38).
} 
fight over free speech, cyber space. ${ }^{4}$ In Levy v. Mahanoy Area School District (Levy), ${ }^{5}$ the Justices will resolve a dispute from Pennsylvania in which the Third Circuit affirmed that educational officials violated a high school cheerleader's First Amendment rights when they punished her for breaking team rules by posting inappropriate messages on her Snapchat account while she was off-campus. ${ }^{6}$

Rather than review the wide array of student speech and expression cases, this article focuses on expressive activity on social media, ultimately zeroing in on Levy in light of the key role that technology continues to play in schools. ${ }^{7}$ As such, the remainder of this three-part article begins by reviewing Tinker before examining the Supreme Court's trilogy of other cases on student expressive activity as well as briefly highlighting illustrative controversies from lower courts. ${ }^{8}$ The second section hones in on Levy while briefly reflecting on its significance as the case heads to the Supreme Court. Then, keeping in mind the importance of treating the law as a practical tool for educational leaders and their lawyers, the third part offers policy suggestions when working with speech codes, broadly defined, as they relate to thorny questions associated with student use of the internet and social media by individuals who are involved in extracurricular activities. The article rounds out with a brief conclusion.

\section{Litigation on Student Expressive Activities}

\subsection{Supreme Court Cases}

\subsubsection{Tinker v. Des Moines Independent Community School District}

The Supreme Court handed down its ground-breaking judgment impacting student free speech rights ${ }^{9}$ in Tinker at the end of what can only be described as a decade of tumultuous change and social upheaval that occurred in the United States during the 1960s. ${ }^{10}$ In Tinker, after the federal trial court in Iowa denied students' claim that a twoday-old board policy that forbade them from wearing black armbands to school in protest of American activity in Viet Nam violated their First Amendment free speech rights, the Supreme Court reversed in their favor.

As an initial matter, using what is now often quoted language, the Tinker Court explained that "[i]t can hardly be argued that either students or teachers shed their constitutional rights to freedom of speech or expression at the schoolhouse gate."11 The Justices thereby sought a middle ground to balance the rights of students against the duty of educators to preserve order and discipline in schools.

Turing to the dispute at bar, the Supreme Court described Tinker as involving "direct, primary First Amendment rights akin to 'pure speech' [that did not concern] ... speech or action that intrudes upon the work of the school or the rights of other students." 12 Put another way, because the arm bands were "pure speech," meaning that whatever messages

4 For relatively early articles on how the law is trying to keep abreast of developments in technology in schools, see (e.g., Black 2015; Russo and Osborne 2012). 376 F. Supp.3d 429 (M.D. Pa. 2019), 964 F.3d 170 (3d Cir. 2020), cert. granted, 2021 WL 77251 (Mem) (2021).

6 For an earlier article on point, see (Osborne and Russo 2012)

7 Use of Technology in Teaching and Learning, United States Department of Education. Available online: https://www.ed.gov/oii-news/usetechnology-teaching-and-learning (accessed on 1 February 2021).

8 For a representative commentary on these cases, see (e.g., Baxter 2014).

9 Presaging the change that was to come, a year before, in Pickering v. Board of Education of Township High School District 205, 391 U.S. 563 (1968), the Supreme Court upheld the free speech rights of teachers in public schools to speak on matters of public concern. In the underlying dispute, the Court found that school board in Illinois could not dismiss a teacher who wrote a letter to a local newspaper criticizing its handling of a bond issue and its allocation of financial resources between its educational and athletic programs.

10 See generally Tinker, 393 U.S. 503. For a discussion of this tumultuous time period, see (Hartman 2015) ANDREW HARTMAN 2015, A WAR FOR THE Soul of America: A History of the Culture WARs 2. Hartman stated:

The sixties gave birth to a new America, a nation more open to new peoples, new ideas, new norms, and, new, if conflicting, articulations of America itself. This fact, more than anything else, helps explain why in the wake of the sixties the national culture grew more divided than it had been in any period since the Civil War 
they communicated depended in part on what observers subjectively perceived, they were entitled to the highest level of protection.

According to the Supreme Court, before school officials could limit student expressive activity, they had to be able to show that their actions were motivated by "more than a desire to avoid the discomfort and unpleasantness that always accompany an unpopular viewpoint. Certainly where there is no finding and no showing that engaging in the forbidden conduct would 'materially and substantially interfere with the requirements of appropriate discipline in the operation of the school,' the prohibition cannot be sustained."13

The Supreme Court subsequently refused to hear an appeal in a case from Ohio, Guzik v. Drebus (Guzick), ${ }^{14}$ upholding a longstanding, albeit unwritten, dress code prohibiting the wearing of buttons or insignia that officials applied universally in a high school which had undergone significant changes in the composition of its student body. The Sixth Circuit affirmed that educational officials did violate the First Amendment by forbidding a student from wearing a button soliciting participation in a demonstration against American activity in Viet Nam because if they had allowed him or others by to wear buttons it could have resulted in a serious discipline problem that would exacerbate racial tensions.

Following Tinker, as viewed through Guzick, the upshot is that courts enter judgments in favor of school officials either if student speech and expression presents reasonable forecasts of material and substantial disruptions and / or carefully crafted dress code policies that are narrowly drawn, are rationally related to legitimate pedagogical concerns in support of schools' educational missions, ${ }^{15}$ and are neither vague nor over-broad. ${ }^{16}$

\subsubsection{Bethel School District No. 403 v. Fraser}

In Bethel School District No. 403 v. Fraser (Bethel), ${ }^{17}$ the Supreme Court returned to the issue of student expression in the form of examined the spoken word. The dispute arose in Washington state when a student made a nominating speech for a peer who was running for a position in student government. The student's speech included graphic sexual language that caused a substantial disruption in his unsuspecting, captive audience. The record revealed that before making the speech, the student ignored suggestions from two educators not to use the offending language. Consequently, the student received a three-day suspension and had his name removed from the list of possible speakers at his graduation. Still, the student was elected by a write-in vote to serve as a graduation speaker.

On further review of an order supporting the student, the Supreme Court reversed in favor of school officials. The Justices reasoned that educators could discipline the student for violating school rules because he delivered the speech after being advised not to do so.

At the heart of its rationale, the Bethel Court acknowledged a key difference between the speech from Tinker. The Court described the armbands in Bethel as a form of pure speech that were passive, nondisruptive expressions of political positions. The Court thus distinguished the speck in Bethel as lewd and obscene, thereby lacking any political viewpoint delivered incident to a student election to an unsuspecting captive audience. Recognizing the duty of educators to inculcate habits and manners of civility while teaching students the boundaries of socially appropriate behavior, the Justices declared that "[t]he determination of what manner of speech in the classroom or in school assembly is inappropriate properly rests with the school board."18

Ibid. at p. 509.

431 F.2d 594 (6th Cir. 1970), cert. denied, 401 U.S. 948 (1971).

15 See, e.g., Blau v. Fort Thomas Public School District, 401 F.3d 381 (6th Cir. 2005); Dempsey v. Alston, 966 A.2d 1 (N.J. Super. Ct. App. Div. 2009), cert. denied, 973 A.2d 386 (N.J. 2009).

16 See, e.g., Canady v. Bossier Parish School Board, 240 F.3d 437 (5th Cir. 2001); Long v. Board of Education of Jefferson County, Kentucky, 121 F. Supp.2d 621 (W.D. Ky. 2000), aff'd, 21 Fed.Appx. 252 (6th Cir. 2001).

17478 U.S. 675 (1986).

18 Ibid. at p. 683. 


\subsubsection{Hazelwood School District v. Kuhlmeier}

Hazelwood School District v. Kuhlmeier (Hazelwood) ${ }^{19}$ addressed the written word in a school-sponsored activity for which students received academic credit. In Hazelwood high school students enrolled in a journalism class in Missouri challenged the actions of their principal, in conjunction with other educators, for deleting two articles, one about teenage pregnancy, the other concerning the divorce of a student's father, from a newspaper they wrote and edited as part of the course for which they received academic credit.

Reversing an earlier order from the Eighth Circuit in favor of the students, the Supreme Court pointed out that the principal acted reasonably. The Justices thought that the principal had the authority to remove the first column in light of its possible identification of unnamed pregnant students along with references to sexual activity deemed inappropriate for some younger readers and the second due to a student's unilateral criticism of her father over the divorce of her parents.

The Supreme Court distinguished Hazelwood from Tinker because the issue in the former focused on the duty of educators to avoid appearing to promote a specific type of speech rather than dealing with the expressive rights of students. As such, the Justices acknowledged the authority of educators over school-sponsored publications and by extension, theatrical productions plus other expressive activities that could reasonably have been perceived as bearing the approval of school officials, however tacitly so.

Ruling in favor of school officials, the Hazelwood Court reasoned that "educators do not offend the First Amendment by exercising editorial control over the style and content of student speech in school-sponsored expressive activities so long as their actions are reasonably related to legitimate pedagogical concerns." ${ }^{20}$ The significance of this language is that if educators meet this standard, whether dealing with student expressive activities or other areas, their actions are likely to withstand challenges.

\subsubsection{Morse v. Frederick}

In Morse v. Frederick (Morse), ${ }^{21}$ the Supreme Court reviewed the free speech rights of students at a school-supervised event. Morse began when a high school principal suspended a student who was at a parade near his school watching the Olympic Torch as it passed through Juneau, Alaska. The principal allowed students and staff who supervised the event to leave class to watch the relay as an approved school event. The principal suspended a student for displaying a large banner which read "BONG HiTS [sic] 4 JESUS,"22 because she interpreted it as advocating illegal drug use, the federal trial court granted the board's motion for summary judgment. On further review, though, the Ninth Circuit reversed in favor of the student.

Reversing in favor of the board, the Supreme Court first rejected the student's claim that he was not engaged in in-school speech. Accepting the principal's interpretation of the banner as logical, the Justices applied in Tinker, Fraser, and Hazelwood in a two-part analysis. First, the Justices noted that the free speech rights of students must be viewed in light of the "special characteristics" ${ }^{23}$ of the school environment. The Court first enunciated this principle in Tinker in order to make it clear that educators were responsible to make sure that students behaved properly while in their care. Second, the Court commented that Tinker was neither absolute nor the only basis on which it could restrict student speech.

Conceding that its Fourth Amendment jurisprudence understood the important, and perhaps even compelling, interest of educators to deter drug use, the Supreme Court agreed that the principal acted properly in disciplining the student for displaying the banner. However, rejecting the board's claim that the principal could have relied on Fraser's

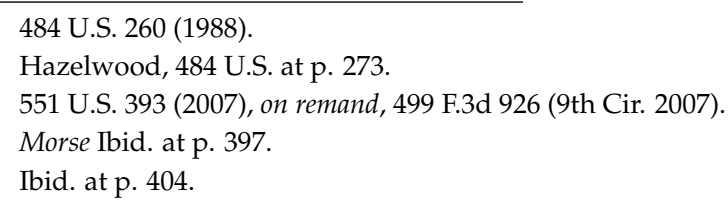


"plainly offensive" 24 standard as affording school officials too much authority, the Justices was convinced that the principal acted out of the legitimate concern of preventing the student from promoting illegal drug use.

\subsection{Illustrative Lower Court Cases on Student Cyber Speech}

As disputes continue over student expressive activity, litigation has generally moved away from issues involving dress and other forms of communication to the cyberspace. As technology continues to become increasingly important in schools, lower courts have reached markedly different outcomes over the extent to which educators can punish students for breaking school rules. This section thus briefly highlights representative litigation involving student use, and misuse of technology, largely in the form of social media, before examining Leoy, the first case in which the Supreme Court will address the limits of school officials to restrict student expression on social media.

Judicial perspectives differ when students are charged with (mis)using social media, especially when they claim that their being disciplined violates their rights to free speech. When courts agree that student messages on the internet are "true threats" or are disruptive, courts have upheld the punishments that school officials impose. ${ }^{25}$ Conversely, courts enter judgments in favor of students if educators fail to demonstrate that their activities were genuinely threating or disruptive. ${ }^{26}$

Courts continue to reach mixed results in another important form of expressive activity as some uphold punishments imposed on students for posting inappropriate messages on social media sites. ${ }^{27}$ Yet, other courts rule in favor of students because they disagree over what is inappropriate. ${ }^{28}$

\section{Levy v. Mahanoy Area School District}

\subsection{Facts}

Levy, a dispute from Pennsylvania focused on the behavior of a first year of high school student, B.L., who joined the junior varsity (JV) cheerleading team at her school. In May of that year, before being able to try out for the varsity team, B.L. and her mother read, signed, and voluntarily agreed to abide by her school's Cheerleading Rules. According to these rules, students must demonstrate "respect for your school, coaches, teachers, other cheerleaders and teams.... Good sportsmanship will be enforced, this includes foul

$24 \quad$ Ibid. at p. 409.

25 See, e.g., D.J.M. ex rel. D.M. v. Hannibal Public School District No. 60, 647 F.3d 754 (8th Cir. 2011) (affirming the disciplinary sanctions imposed on a high school student who sent instant messages from his home to a classmate in which he talked about obtaining a gun and shooting peers at school because officials deemed them credible); Wisniewski v. Board of Educ. Weedsport Central School District, 494 F.3d 34 (2d Cir. 2007), cert. denied, 552 U.S. 1296 (2008) (upholding the discipling of a student who created and transmitted drawings depicting the shooting of a teacher because they posed a reasonably foreseeable risk that they would come to attention of school officials resulting in a material and substantial disruption to the work and discipline of the school.)

26 Burge ex rel. Burge v. Colton School District 53, 100 F. Supp.3d 1057, 1060 (D. Or. 2015) (refusing to treat a middle school student's comment that a teacher "needed to be shot" as a true threat but rejecting the claim that the three and one half day in-school suspension he received did not deprive him of a property interest protected by due process).

27 A.N. ex rel. Niziolek v. Upper Perkiomen School District, 2017, 228 F. Supp.3d 391 (E.D. Pa. 2017) (denying a high school student's request for a preliminary injunction ordering his reinstatement where his out-of-school media post of a video threatening violence caused a substantial disruption in his school before the start of the day which resulted in the superintendent canceling school for the safety and well-being of students); Dunkley v. Board of Education of the Greater Egg Harbor Regional High School District, 216 F. Supp.3d 485 (D.N.J. 2016) (denying a student's motion for summary judgment after he was suspended for making inappropriate comments about classmates in out-of-school social media posts on Twitter because his comments were exactly of the type a state anti-bullying law sought to prohibit, he had no basis on which to challenge his suspension).

28 For two cases the Third Circuit resolved in favor of students on the same day with like outcomes, see Layshock ex rel. Layshock v. Hermitage School District, 650 F.3d 205 (3d Cir. 2011), cert. denied, 565 U.S. 1156 (2012) (affirming that school officials violated the First Amendment rights of a student they suspended for using his grandmother's home computer to create a fake internet profile of his principal, rejecting their defense that they could punish pupils for engaging in expressive conduct outside of school they considered to be lewd and offensive; J.S. ex rel. v. Blue Mountain School District, 650 F.3d 915 (3d Cir. 2011), cert. denied, 565 U.S. 1156 (2012) (deciding that that officials violated the rights of an eighth-grade student who used her home computer to create a fake profile of her principal, insinuating, among other things, that he was a sex addict and a pedophile because she took specific steps to try to keep the profile "private" so only her friends could access it and it was so outrageous as to not be taken seriously; the court added that educators violated her rights because they could not reasonably have forecast a substantial disruption of, or material interference with, school activities due to the posting). 
language and inappropriate gestures." 29 The rules added "[ $t]$ here will be no toleration of any negative information regarding cheerleading, cheerleaders, or coaches placed on the internet." ${ }^{30}$

Following varsity tryouts, because she did not do well, B.L. returned to the JV squad even though a first-year student qualified for membership on the varsity team. Upset and frustrated over the tryout and failing to make the varsity squad, unhappy about her position on a local softball team, and worried about upcoming examinations, B.L. met a friend on a Saturday at a local off-campus store. ${ }^{31}$ At the store, B.L. "took a photo of herself and her friend with their middle fingers raised and posted it to her Snapchat story. The snap was visible to about 250 'friends,' many of whom were MAHS [district] students and some of whom were cheerleaders, and it was accompanied by a puerile caption: 'F-school $\mathrm{f}$ - softball $\mathrm{f}$-cheer $\mathrm{f}$ - everything."'”32

After coaches learned of B.L.'s "Snap," they decided that it violated both school and team rules that she and her mother willingly signed before trying out for cheerleading, particularly not to use "'foul language and inappropriate gestures;' and refrain from sharing 'negative information regarding cheerleading, cheerleaders, or coaches ... on the internet' and another rule to 'conduct[] themselves in such a way that the image of the Mahanoy School District would not be tarnished in any manner.'"'33 Consequently, coaches removed B.L. from the squad for a year but "would not have suspended B.L. from the team if her Snaps had not referenced cheerleading." ${ }^{134}$ Dissatisfied with her having been suspended from the cheerleading squad, the student and her parents sued their school board and various educational officials.

\subsection{Judicial History}

\subsubsection{Federal Trial Court Order}

A federal trial court in Pennsylvania granted the plaintiffs' request for a temporary restraining order and preliminary injunction returning B.L. to the team. The court entered the order in favor of the plaintiffs because it was persuaded that they were likely to prevail on the merits of their claim that school officials violated her First Amendment right by suspending B.L. for her off-campus use of vulgar language even though she and her mother freely signed a form agreeing to abide by its provisions. Dissatisfied with the outcome, the board appealed to the Third Circuit.

\subsubsection{Analysis of the Third Circuit's Order}

On further review, a unanimous judgment, in what it described as a case of first impression, the Third Circuit affirmed in favor of B.L. even though she violated team rules by posting her off-campus, profanity-laden statement on her Snapchat account plus a photograph of herself and a friend making an obscene gesture after she failed to qualify for the varsity cheerleading team. In its analysis, the court ignored not only its own precedent about extra-curricular activities as privileges from Palmer v. Merluzzi (Palmer), ${ }^{35}$ discussed below $^{36}$, but also cases from other circuits penalizing students' off-campus misuse of social media. ${ }^{37}$

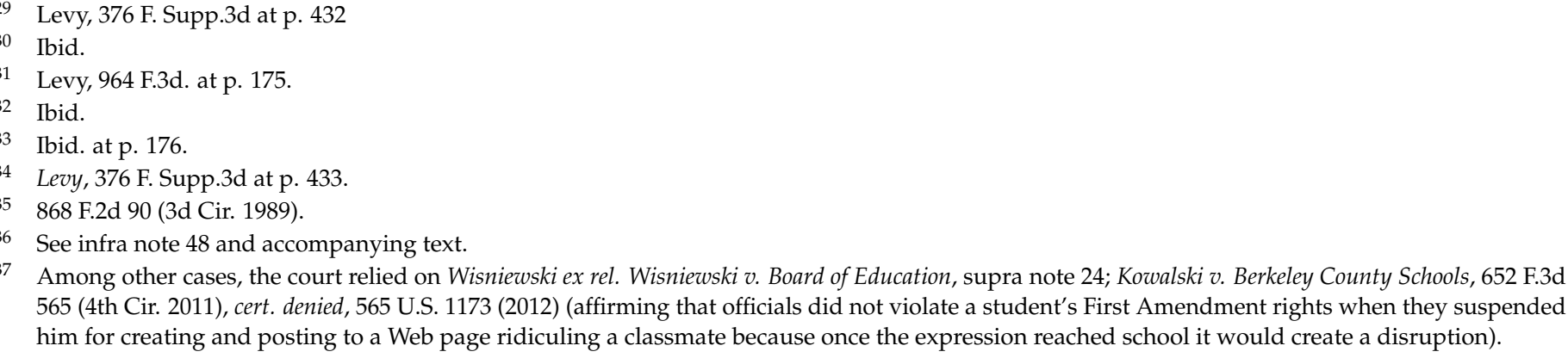

7 Among other cases, the court relied on Wisniewski ex rel. Wisniewski v. Board of Education, supra note 24; Kowalski v. Berkeley County Schools, 652 F.3d 565 (4th Cir. 2011), cert. denied, 565 U.S. 1173 (2012) (affirming that officials did not violate a student's First Amendment rights when they suspended him for creating and posting to a Web page ridiculing a classmate because once the expression reached school it would create a disruption). 
After citing the First Amendment, that "Congress shall make no law ... abridging the freedom of speech,"38 the court began its analysis by declaring that B.L.'s "Snap" was entitled to First Amendment protection. Not surprisingly, the court reviewed the relevant Supreme Court cases on student expressive activity starting with Tinker. The Third Circuit relied on two key points from Tinker, noting that "[i]t can hardly be argued that either students or teachers shed their constitutional rights to freedom of speech or expression at the schoolhouse gate." 39 The panel also relied on Tinker for the proposition that educators can limit student speech only if it "would 'materially and substantially interfere with the requirements of appropriate discipline in the operation of the school.'"40

Describing Tinker as striking a balance between student expressive activities and educators' duty to maintain safe and orderly learning environments, the Third Circuit reviewed various cases, most notably one of its own earlier judgments in J.S. ex rel. Snyder $v$. Blue Mountain School District (Blue Mountain), ${ }^{41}$ reiterating that under Tinker officials cannot limit student expressive activity absent "a specific and significant fear of disruption." The Blue Mountain court held that officials violated the rights of an eighth-grader who used her home computer to create a fake profile of his principal, insinuating, among other things, that the educator was a sex addict and a pedophile. The Blue Mountain court was of the opinion that because the profile was so outrageous that readers could not have taken it seriously, educators violated the student's rights insofar as they could not reasonably have forecast it as causing a substantial disruption of, or material interference with, school activities.

Having determined that the First Amendment protected B.L.'s speech, the Third Circuit considered where it occurred. Among other cases, the court largely relied on Layshock ex rel. Layshock $v$. Hermitage School District (Layshock) ${ }^{42}$ wherein it affirmed that officials violated the First Amendment rights of a student they suspended for using his grandmother's home computer to create a fake internet profile of his principal including statements that he smoked marijuana, used other drugs, and drank too much alcohol. The court invalidated the punishment because the student was not in school when he created the profile. Commenting that the Supreme Court has yet to address the distinction between in-school and out-of-school speech, the Third Circuit again relied heavily on Blue Mountain and Layshock, reiterating the obvious, namely that B.L.'s speech occurred off campus.

The Levy court then observed that B.L.'s suspension violated her First Amendment rights, rejecting the board's reliance on Bethel. The court rejected Fraser as inapplicable because while it involved a vulgar nominating speech in school after being advised not to do so, Levy involved a speech that not only occurred off-campus but on a Saturday. The court again cited Blue Mountain and Layshock as defending the free speech rights of students among the cases it discussed.

The Third Circuit next applied a two-step analysis to the board's attempted reliance on Tinker's disruption standard. First, the court reviewed the judgments of other circuits that applied Tinker in similar contexts but rejected them as expanding its narrow justification for limiting student speech too broadly, allowing officials to restrict what it considered protected speech. Second, the court contended that because Tinker is inapplicable to offcampus speech, officials violated B.L.'s First Amendment rights in disciplining her for her out-of-school posting on Snapchat.

At the outset of the final part of its analysis, the Third Circuit rejected the board's arguments that B.L.'s vulgar language was not entitled to protection, that she did not express an opinion, and that her profane speech directed toward minors was unprotected. The court maintained that B.L.'s protected speech was beyond the boundaries of Tinker and Fraser. Finally, the court rejected the board's reliance on the fact that B.L. and her mother

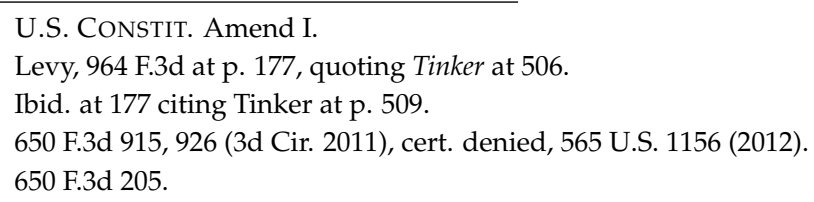


willingly signed an agreement not to behave as she did by treating it as inapplicable outside of the season and rejecting its description of prohibited behaviors as lacking clarity.

In the final paragraph of its opinion, the majority conceded that " $[\mathrm{t}] \mathrm{o}$ be sure, B.L.'s snap was crude, rude, and juvenile, just as we might expect of an adolescent. But the primary responsibility for teaching civility rests with parents and other members of the community." 43 The court then decreed that officials in public schools "may not leverage the coercive power with which they have been entrusted to do so. Otherwise, we give school administrators the power to quash student expression deemed crude or offensivewhich far too easily metastasizes into the power to censor valuable speech and legitimate criticism." ${ }^{\prime 4}$ The Third Circuit thus affirmed that educators violated B.L.'s First Amendment rights by suspending her from the cheerleading squad due to the content of her offcampus speech.

\subsubsection{Analysis of the Concurrence}

The third member of the court bench agreed with the judgment in favor of the student and her parents. ${ }^{45}$ However, the judge concurred separately because he disagreed with the court's rejection of applying Tinker to student off-campus speech insofar as he would have grounded its judgment in Blue Mountain and Layshock.

\subsection{Reflections on Levy}

Readily acknowledging that B.L's "Snap" was "puerile," 46 "crude, rude, and juvenile," ${ }^{\prime 47}$ amazingly, the Third Circuit surprisingly ignored another one of its own precedents, Palmer v. Merluzzi, discussed in the following two paragraphs. In so finding, the court affirmed that educators violated B.L.'s First Amendment rights when they suspended her from her school's cheerleading team, ignoring Palmer and the fact that her participation was a privilege and not a right, instead focusing on in Blue Mountain and Layshock. The court also failed to afford due significance to the fact that B.L. and her mother voluntarily signed a form pledging to abide by team, and school, rules.

The Third Circuit acknowledged that according to the "Personal Conduct Rule" in the student handbook, "[p]articipation on an athletic team or cheerleading squad in the Mahanoy Area School District is a privilege." 48 Yet, it is surprising that the panel ignored its own precedent from Palmer, ${ }^{49}$ that participating in extracurricular activities is a privilege, not a right, affirming that school officials in Mahanoy violated the student's First Amendment rights in suspending her from the cheerleading team for a year.

In Palmer the Third Circuit upheld a student-athlete's ten-day suspension for smoking marijuana and consuming beer in his school radio station during non-class hours. The court also upheld the student-athlete's sixty-day suspension from football, essentially ending his career as it rejected his argument that this would have a significantly adverse effect on his chances for a college football scholarship. Instead, the court emphasized that because participation in extracurricular activities is a privilege, not a right, students can be subject to more stringent disciplinary codes because they freely chose to participate and comply with team and activity rules.

Consistent with its two earlier orders in favor of students who engaged in questionable use of social media and the internet in Layshock and Blue Mountain, the Third Circuit reached a similar outcome in Levy. One can only wonder what message the Third Circuit's holding sent to students, let alone parents, in Mahanoy by ignoring the fact that B.L. and her mother freely agreed to follow team rules due to her participation in cheerleading in stating that

Levy, 964 F.3d. at p. 194.

44 Ibid.

45 Ibid. at p. 194 (Ambro, J., concurring).

46 Id at p. 175.

7 Ibid. at p. 194.

48 Ibid. at p. 193.

49 Supra note 34. 
"the primary responsibility for teaching civility rests with parents and other members of the community." 50

The Third Circuit's rejection of the authority of educators stands in direct conflict with the Supreme Court's assertion in Bethel that "[t]he process of educating our youth for citizenship in public schools is not confined to books, the curriculum, and the civics class; schools must teach by example the shared values of a civilized social order." ${ }^{\prime 51}$ Further, insofar as the student in Levy clearly flaunted a rule governing her participation in a privileged extracurricular activity, of which she was aware, it remains to be seen whether the Supreme Court will allow this judgment to continue to undermine the authority of school officials.

While one can perhaps argue that the policy's language could have more clearly addressed the timing and content of off-campus expressive activity reflecting poorly on the school, Levy is likely to create confusion for boards and officials such as coaches and moderators in Delaware, New Jersey, and Pennsylvania, the jurisdictions comprising the Third Circuit. At a time when school discipline seems to be lacking, it is unfortunate that the court failed to provide positive guidance for school officials.

The Third Circuit's argument to the contrary, rejecting the board's reliance on the fact that the student and her mother freely signed the consent form for participating on the team, a good case can be made that such forms are valuable for four reasons. First, by having students involved in what was clearly described in Levy as a privileged activity, rather than an entitlement or right, sign these forms, they can help them to learn that their words mean something. Second, by having students sign forms, educational officials can hope to maintain reasonable control over school-sponsored activities in which participants represent the good names of their school systems.

In a third closely related point, by having students sign good conduct forms, educators can help them to learn that they must think about what they are saying online and that their actions have consequences because they may can be held accountable for their behavior. Fourth, high school, and indeed younger, students must learn that there are limits on what they can say online, let alone in person, as they balance their rights to expression against reasonable limits on can post on social media sites as they grow toward responsible adulthood.

It remains to be seen how the Supreme Court resolves this morass in Levy because it stands contrast to a case from Colorado, albeit from a federal trial court. The court in Colorado, in a similar set of facts, refused to enjoin school officials who removed a cheerleader from her team. The student was removed from the team because she posted an eight-second video on Snapchat in which she used inappropriate language and disclosed information about making the squad that coaches and others asked her not to reveal until they had spoken with others who tried out for the activity. ${ }^{52}$

It is of utmost importance that the Supreme Court continue to recognize and support the duty of educational officials to maintain safe and orderly learning environments by being able to discipline students whose disrespectful uses of social media may result in material and substantial disruptions and harm to peers if they become known in schools. Safeguarding the authority of educators to discipline students who misuse social media in clear violation of school rules and agreements that they, along with their parents, signed as part of the process in becoming involved in privileged extracurricular activities is of paramount importance. Educators must be able to exert such reasonable rules if they

$50 \quad$ Levy, 964 F.3d. at p. 194.

51 Bethel, 478 U.S. at p. 683.

52 Johnson v. Cache County School District, 323 F. Supp.3d 1301, 1320 (D. Utah 2018). In addition, the court rejected the student's claim that her being removed from the team caused her an irreparable harm because officials provided her with an opportunity for the plaintiff to regain her position by performing community service, apologizing, and writing a report on the appropriate use of social media which she and her father unambiguously rejected. In its analysis, the court distinguished Levy, admittedly only a trial court case at that time, pointing to the degree of the student's insubordination because officials specifically asked her not to post anything online about being selected to the squad until the next day by which time coaches could have notified those who did not make the squad. 
are going to be able to meet their duty to maintain orderly, well-functioning learning environments.

Concomitantly, while educators must certainly respect the rights of students to express themselves freely whether on social media or elsewhere, this is a responsibility that goes both ways. In other words, because school officials have the authority to enact reasonable guidelines governing student participation in extracurricular activities, students, with their parents, must demonstrate respect for rules designed to enhance the ability of educators to provide safe environments in which all pupils can learn safely and participate freely. ${ }^{53}$

\section{Policy Suggestions}

In anticipation of the Supreme Court's judgment in Levy, this section offers suggestions for attorneys and educational leaders to consider when devising and revising their codes of conduct policies for student speech and internet postings that can withstand constitutional challenges as they seek to regulate pupil participation in extracurricular activities. While it remains to be seen how the Supreme Court rules in Levy, most of these suggestions should remain viable regardless of the outcome in this case.

1. When writing and revising policies on extracurricular activities, particularly in connection with use of social media and other forms of the internet, educational leaders, working in conjunction with their attorneys, should seek input from parents because their support is crucial. While certainly not wishing to grant them a "heckler's veto," as reflected in Levy, in particular, if parents are unwilling to support speech and discipline policies, including those they freely signed with their children; however widely defined, educational leaders may want to consider gaining their support before acting. Making sure to gain support is important because if parents are uncooperative, disputes over school rules can unnecessarily consume a great deal of district time, energy, and money without reaching desired or productive outcomes.

2. Teams that write and revise policies should include a wide range of individuals in order to take variety of perspectives into consideration. Teams should include a board member, building and district level administrators, a teacher, the board's attorney, a parent, and perhaps a secondary school student to obtain their input at the "ground level."

3. Subject to the Supreme Court's judgment in Levy, and assuming that its rationale is consistent with Palmer, policies should clearly state that because participation in extracurricular activities is a privilege in which students take part voluntarily, not a right, they can be subject to more stringent disciplinary standards than their non-participating peers. To date, beyond the Third Circuit, courts have agreed that students in extracurricular activities can be held to these higher standards. ${ }^{54}$ As such, it would be surprising for the Supreme Court to ignore this basic principle. In a related item, particularly in sports, but certainly not limited to athletics, because student-athletes have opportunities for notoriety and scholarships, they are expected to display exemplary behavior as representatives of their schools and teams.

4. In conjunction with the board attorneys, policy writing and/or revising teams should review judicial precedent in their circuits and/or jurisdictions as well as state statutes and/or regulations. Teams should also examine policies of their state extracurricular activities organizations addressing the extent to which educators can adopt and enforce policies governing the expressive out-of-school conduct of students involved in extracurricular activities.

5. To the extent possible, policies should provide examples of forbidden speech and expressive activity, a point the Levy court relied on in invalidating the student's punishment. Policies should thus use clear, concise language carefully defining the

53 For a relatively early commentary on the role of school officials in this area, see (Wolking 2008).

54 See, e.g., Vernonia School District 47J v. Acton, 515 U.S. 646, 657 (1995) (upholding mandatory random urinalysis for students participating in interscholastic athletics; "students who voluntarily participate in school athletics have reason to expect intrusions upon normal rights and privileges."). 
limits on student expressive activities. Because the biggest threat to speech policies, again broadly defined, is the charge of being vague and/ or over-broad, precision is crucial. While no policy can cover every issue involving student expressive activities, policies should include such language as "this includes ... but is not limited to ..." Courts tend to defer to educators when dealing with otherwise well-crafted up-to-date policies including such expansive language because they realize that the fact-specific nature of disputes, coupled with how rapidly change occurs in technology and cyberspace, make it almost impossible to set precise limits.

6. Policies should specify that "good behavior" provisions apply regardless of whether students are, for instance, in games, practices, or rehearsals, whether on weekends, on-campus or off-campus ${ }^{55}$, in-season, or out-of-season.

7. Depending on how the Supreme Court resolves Levy, policies should require parents and students to sign a form indicating that they will comply with activity and school rules. As an added precaution, policies should have students and parents initial key provisions such as those subject to litigation in Levy, expecting participants in extracurricular activities to avoid foul language and inappropriate gestures, particularly when their postings on social media can be readily associated with their schools and activities.

8. Policies should address the due process rights of students who violate team and activity rules. When imposing punishments, policies should include progressive levels of discipline, outlining sanctions for first and subsequent offences during the same, and perhaps subsequent, academic years. Ultimately, sanctions might include parental conferences to try to understand why students are unwilling to cooperate with team and activity rules. Moreover, policies should address whether, and how, students can appeal their punishments.

9. Policies should consider rewarding students who comply with policies by, for example, providing them with free lunches or allowing them "dress down" days if schools have dress code policies.

10. Educational leaders should communicate policies to faculty and staff at meetings as well as by including them their handbooks. It almost goes without saying that educational leaders should remind teachers to apply policies consistently to avoid charges of favoritism.

11. Coaches and moderators should keep parents and students informed about policies by including them in student handbooks, materials sent home, and/or on district websites, particularly those associated with their activities.

12. As extracurricular activities are integral to student development, educational leaders and lawyers should review, and, if necessary, revise, their policies during summer retreats to ensure their smooth operations. It is better to not review policies during or shortly after controversies, because placing a "cooling off period" between conflicts and reviews affords better perspective. Another value in reviewing policies regularly is that in the event of litigation, evidence of their having been updated can help to convince courts that educators did their best to be current, while safeguarding student rights in the face of rapid changes in both the law and social media.

\section{Conclusions}

There can be little doubt that the free speech and expression rights of students in American public schools are of paramount importance. Yet, in seeking to ensure that students engaged in activities in which they represent their schools do so well, educational officials must preserve their authority to limit inappropriate expression on new and emerging forms of technology as exemplified by social media. ${ }^{56}$ Thus, it will be interesting to see whether

55 For a commentary on this persistent issue, see (Daniel 2011, p. 21).

56 Justice Black's dissent, joined by Justice Harland, supports this concern that the opinion of the Court may well have undermined the legitimate authority of school officials. Tinker, 393 U.S. at 515 (Black, J., dissenting). The Court largely validated Justice Black's concern by limiting student expressive rights in schools in Bethel, Hazelwood, and Morse. 
the Supreme Court's judgment in Levy follows the lead of its three cases subsequent to Tinker, Bethel, Hazelwood, and Morse, by upholding the authority of educators to apply reasonable limits on what students can, and do, on social media platforms whether on or off-campus if they take part in such privileged events as extracurricular activities.

\section{Postscript}

As this article heads to press, two important developments have emerged. First, the Supreme Court will hear oral arguments in Levy on April 28, 2021. ${ }^{57}$ Second, the Biden administration, ${ }^{58}$ along with others, ${ }^{59}$ have entered amici curiae, "friend of the Court" briefs, demonstrating their support for the school board in Levy. The Court is expected to hand down a decision by late June 2021.

Funding: This research received no external funding.

Institutional Review Board Statement: Not applicable.

Informed Consent Statement: Not applicable.

Data Availability Statement: Not applicable.

Conflicts of Interest: The author declares no conflict of interest.

\section{References}

Baxter, Lee C. 2014. The Unrealistic Geographic Limitations of The Supreme Court's School-Speech Precedents: Tinker In The Internet Age. Montana Law Review 75: 103.

Black, Watt Lesley. 2015. Omnipresent Student Speech and the Schoolhouse Gate: Interpreting Tinker in the Digital Age. Saint Louis University Law Journal 59: 531.

Daniel, Philip T. K. 2011. A Need To Sharpen The First Amendment Contours Of Off-Campus Student Speech. Education Law Reporter 273: 21-45.

Hartman, Andrew. 2015. A War for the Soul of America: A History of the Culture Wars. Chicago: University of Chicago Press.

Osborne, Allan G., and Charles J. Russo. 2012. Can Students be Disciplined for Off-campus Cyberspeech: The Reach of the First Amendment in the Age of Technology. Brigham Young University Education and Law Journal 2021: 331-67.

Papandrea, Mary Rose. 2019. The Great Unfulfilled Promise of Tinker. Virginia Law Review Online 105: 159.

Russo, Charles J. 2018. Technology in Schools: The Only Constant is Change. School Business Affairs 84: 35-38.

Russo, Charles J., and Allan G. Osborne. 2012. Can the Law Keep Pace with Technology? Regulating Student Use of the Internet and Cyberspace. School Business Affairs 78: 35-38.

Sweeney, Allison N. Fall. 2018. The Trouble with Tinker: An Examination of Student Free Speech Rights in the Digital Age. Fordham Intellectual Property, Media and Entertainment Law Journal 29: 359.

Wolking, Tova. 2008. School Administrators as Cyber Censors: Cyber Speech and First Amendment Rights. Berkeley Technology Law Journal 23: 1507.

57 U.S. Supreme Court, Monthly Argument Calendar, April 2020. Available online: https://www.supremecourt.gov/oral_arguments/argument_ calendars/monthlyargumentcalapril2021.pdf (accessed on 15 March 2021).

58 Brief for the United States as Amicus Curiae Supporting Petitioner, 2021 WL 859695, No. 20-255, March 2021.

59 See, e.g., Brief for Pennsylvania School Boards Association and Pennsylvania Principals Association as Amici Curiae in Support of Petitioners, 2021 WL 859699, 1 March 2021. 